\title{
ISOLASI DAN KARAKTERISASI Staphylococcus aureus DARI SUSU KAMBING DAN PRODUK OLAHANNYA
}

\author{
[Isolation and Characterization of Staphylococcus aureus \\ from Goat Milk and Dairy Products]
}

\author{
Widodo Suwito $^{1) \star}$, Erna Winarti ${ }^{1)}$, Ari Widyastuti ${ }^{1}$, Felisitas Kristiyanti ${ }^{2)}$, dan Andriani ${ }^{3)}$ \\ 1) Balai Pengkajian Teknologi Pertanian Sleman, Yogyakarta \\ 2) Dinas Pertanian, Perikanan, dan Kehutanan Kabupaten Sleman, Yogyakarta \\ 3) Balai Besar Penelitian Veteriner, Bogor
}

Diterima 13 April 2017 / Disetujui 16 Juni 2017

\begin{abstract}
Presence of Staphylococcus aureus in goat milk and dairy product could lead to human illness. The aim of the present study was to characterize S. aureus isolated from goat milk and its products. The samples used in these studies were taken from goat farm and a goat milk processing facility in Sleman district. Characterization of the $S$. aureus was based on biochemical reaction, namely haemolysin activity, clumping factor, coagulase activity, and resistance against antibiotics. The haemolysin activity was determined by culturing the isolates on blood agar plates, whereas clumping factor with slide agglutination test. Mixing the rabbit plasma and culture S. aureus was used to determine the coagulase activity, while antibiotics susceptibility was carried out with agar diffusion test. The resulst showed that the number of $S$. aureus detected in 86\% of goat milk samples conformed with SNI No 01-6366-2000. The characteristics of S. aureus from goat milk samples showed that $80 \%$ of the S. aureus isolates were non haemolytic, $20 \%$ were positive for clumping factor, and $40 \%$ were positive for coagulase activity. The antibiotic resistance test for S. aureus isolated from the goat milk samples suggested that $30 \%$ was resistant to ampicillin and penicillin while 10\% showed resistance to erythromycin, neomycin, sulfonamide, and tetracycline.
\end{abstract}

Keywords: characterization, goat milk, Staphylococcus aureus

\section{ABSTRAK}

Keberadaan Staphylococcus aureus pada susu kam bing dan produk olahannya dapat menyebabkan penyakit pada manusia. Tujuan penelitian ini untuk isolasi dan karakterisasi $S$. aureus dari susu kambing dan produk olahannya. Susu kambing dan produk olahannya yang digunakan dalam penelitian ini diambil dari peternakan kambing dan tempat pengolahan susu kambing di kabupaten Sleman. Isolasi $S$. aureus berdasarkan reaksi biokimia. Karakterisasi $S$. aureus dilakukan terhadap hemolisin, klumping faktor, koagulase, dan sensitifitas antibiotik. Hemolisin ditentukan dengan kulture pada blood agar plate, sedangkan klumping faktor dengan slide agglutination test. Mencampur plasma kelinci dengan kulture cair $S$. aureus dalam tabung reaksi digunakan untuk deteksi koagulase, sedangkan sensitifitas antibiotik dengan agar difusi. Hasil analisis menunjukkan bahwa susu kambing dengan jumlah $S$. aureus yang masih memenuhi ketetapan SNI No 01-6366-2000 sebanyak $86 \%$. S. aureus dari susu kambing memiliki karakter tidak hemolitik $80 \%$, klumping faktor positif $20 \%$, koagulase positif $40 \%$, resisten terhadap ampisilin dan penisilin 30\%, sedangkan terhadap eritromisin, neomisin, sulfonamide, dan tetrasiklin masing-masing $10 \%$.

Kata kunci: karakterisasi, Staphylococcus aureus, susu kambing

\section{PENDAHULUAN}

Staphylococcus aureus merupakan bakteri Gram positif, bersifat fakultatif anaerob, tidak menghasilkan spora, tidak bergerak, katalase positif, oksidase negatif, berbentuk coccus dan banyak terdapat pada permukaan kulit manusia maupun

*Penulis Korespondensi:

E-mail: widodo.suwito@yahoo.com hewan (Tong et al., 2015). Faktor virulensi S. aureus merupakan hal yang penting untuk menimbulkan penyakit. Beberapa faktor virulensi $S$. aureus antara lain tipe antigen permukaan, enzim koagulase, enterotoksin, leukosidin, dan hemolisin. Enterotoksin merupakan faktor virulensi yang penting dalam foodborne diseases karena toksin tersebut tahan pada suhu $110^{\circ} \mathrm{C}$ selama 30 menit. Staphylococcus aureus dalam jumlah $>10^{5}-10^{6} \mathrm{CFU} / \mathrm{g}$ berpotensi menghasilkan toksin dengan konsentrasi $1 \mu \mathrm{g}$ (Ertas 
et al., 2010). Minum susu kambing pada sebagian masyarakat bertujuan untuk menjaga kesehatan dan menambah stamina. Dibandingkan dengan susu sapi, susu kambing mempunyai kelebihan seperti kandungan protein yang tinggi, sumber mineral, kalsium, dan posfor (Albenzio dan Santillo, 2011). Selain itu, susu kambing juga mempunyai butir lemak yang kecil dan asam lemak rantai pendek yang banyak sehingga susu kambing mudah dicerna (Ceballos et al., 2009). Oleh karena susu kambing mudah dicerna, maka susu kambing dapat diberikan pada orang yang alergi terhadap susu sapi terutama pada anak-anak maupun orang dewasa. Susu kambing dapat diberikan pada anak-anak maupun orang dewasa dengan tujuan untuk menjaga kesehatan (Ribeiro, 2010).

Kabupaten Sleman merupakan daerah penghasil susu kambing dan tempat pengolahan susu kambing menjadi produk olahan seperti susu kambing bubuk, permen, krupuk, yoghurt, dan es krim. Produksi susu kambing di Kabupaten Sleman sekitar 4593 liter/tahun sedangkan produksi olahan susu kambing mencapai 6 kuintal per hari (SIDa, 2013). Sampai saat ini pemerahan kambing di Kabupaten Sleman masih menggunakan tangan. Hal tersebut menyebabkan susu kambing berisiko terkontaminasi $S$. aureus, karena tangan pemerah dapat sebagai sumber $S$. aureus. Selain itu, produk olahan susu kambing seperti susu bubuk atau olahan lainnya dalam skala rumah tangga yang masih sederhana berisiko terkontaminasi $S$. aureus. Oleh karena itu penelitian ini dilakukan untuk isolasi dan mengkarakterisasi $S$. aureus dari susu kambing dan produk olahannya.

\section{BAHAN DAN METODE}

\section{Bahan}

Bahan yang digunakan dalam penelitian ini adalah susu kambing sebanyak 15 sampel dan produk olahan berbasis susu kambing seperti susu bubuk, permen, es krim, yoghurt dan krupuk sebanyak 10, 3, 6, 4, dan 3 sampel. Sampel tersebut diambil dari peternakan kambing dan tempat pengolahan susu kambing di Kabupaten Sleman, Yogyakarta. Pengambilan sampel dilakukan secara proporsional sesuai ketersediaan sampel di peternakan kambing dan tempat pengolahan susu kambing.

\section{Isolasi dan penghitungan Jumlah $S$. aureus}

Isolasi dan jumlah $S$. aureus dengan metode BAM (2011). Sampel (susu kambing, es krim, dan yoghurt) sebanyak $5 \mathrm{~mL}$ dan sampel olahan berbasis susu kambing (susu bubuk, permen, dan krupuk) sebanyak 25 gram dimasukan dalam $50 \mathrm{~mL}$ buffer peptone water (BPW) (Oxoid Ltd., Basingstoke, United Kingdom) selanjutnya diinkubasikan suhu $37^{\circ} \mathrm{C}$ selama $24-48$ jam. Subkultur pada mannitol salt agar (MSA) (Oxoid Ltd., Basingstoke, United Kingdom) dan diinkubasikan suhu $37^{\circ} \mathrm{C}$ selama 24 jam. Koloni berwarna kuning licin yang diduga $S$. aureus dilakukan pewarnaan Gram, uji katalase, dan uji biokimiawi (Tong et al., 2015). Sampel yang positif $S$. aureus dilanjutkan penghitungan jumlah $S$. aureus dengan pengenceran menggunakan BPW sampai pengenceran $10^{-6}$. Selanjutnya masing-masing enceran diambil $1 \mathrm{~mL}$ dimasukkan cawan petri steril, kemudian dituang vogel johson agar (VJA) (Oxoid Ltd., Basingstoke, United Kingdom) yang sebelumnya ditambah potassium tellurite $1 \%$. Selanjutnya dihomogenkan, jika sudah membeku diinkubasikan suhu $37^{\circ} \mathrm{C}$ selama 24-48 jam. Koloni yang dihitung berbentuk bulat, licin, berwarna abu-abu sampai hitam pekat yang dikelilingi oleh zona yang bening.

\section{Produksi hemolisin}

Produksi hemolisin S. aureus berdasarkan terbentuknya zona hemolitik pada blood agar plate (BAP). Staphylococcus aureus dikultur pada BAP (Oxoid Ltd., Basingstoke, United Kingdom) kemudian diinkubasikan suhu $37^{\circ} \mathrm{C}$ selama 24 jam. Tipe hemolitik $S$. aureus dikelompokan menjadi tiga yaitu $\alpha, \beta$, dan tidak hemolitik atau y (Tong et al., 2015). Tipe a hemolitik apabila disekitar koloni $S$. aureus tampak terang, $\beta$ hemolitik akan terlihat agak gelap disekitar koloni, dan tidak hemolitik atau $\mathrm{y}$ apabila disekitar koloni tetap berwarna merah.

\section{Klamping faktor}

Deteksi klamping faktor $S$. aureus dengan slide agglutination test. Satu koloni $S$. aureus diambil dari BAP dengan Ose steril dan dicampur dengan akuades steril sampai homogen atau terbentuk suspensi $S$. aureus. Suspensi $S$. aureus tersebut ditetesi dengan plasma kelinci sebanyak dua tetes, kemudian diaduk dengan Ose steril dan amati terbentuknya agglutinasi. Klumping faktor positif apabila terjadi aglutinasi antara suspensi $S$. aureus dan plasma kelinci, dan negatif apabila suspensi $S$. aureus tetap homogen setelah ditambah plasma kelinci (Tong et al., 2015).

\section{Koagulase}

Deteksi enzim koagulase dengan tabung atau tube coagulation test. Kultur $S$. aureus dalam $5 \mathrm{~mL}$ brain heart infusion (BHI) (Oxoid Ltd., Basingstoke, United Kingdom) dan inkubasikan suhu $37^{\circ} \mathrm{C}$ selama 24 jam. Selanjutnya campur dengan plasma kelinci dengan volume yang sama, kemudian diinkubasi di dalam water bath pada suhu $37^{\circ} \mathrm{C}$. Selanjutnya amati terbentuknya gel dalam waktu 15 menit, 30 menit, dan 60 menit (Tong et al., 2015). 


\section{Sensitifitas antibiotika}

Sensitifitas antibiotika terhadap $S$. aureus terhadap antibiotika diukur dengan agar difusi menggunakan kertas cakram (disc) antibiotika yang sudah diketahui konsentrasinya. Staphylococcus aureus dikultur dalam $\mathrm{BH}$ dan diinkubasikan pada suhu $37^{\circ} \mathrm{C}$ selama 24 jam. Sebanyak $1 \mathrm{~mL}$ biakan $\mathrm{BHI}$ tersebut diteteskan pada permukaan mÜeller hinton agar (MHA) (Oxoid Ltd., Basingstoke, United Kingdom) yang selanjutnya diratakan dan dikeringkan dalam inkubator selama 10 menit. Media MHA yang sudah diinokulasi $S$. aureus tersebut selanjutnya ditempeli kertas cakram (disc) antibiotika dan diinkubasi pada suhu $37^{\circ} \mathrm{C}$ selama 24 jam. Interpretasi sensitifitas antibiotika menurut CLSI (CLSI, 2012).

\section{HASIL DAN PEMBAHASAN}

Keberadaan $S$. aureus pada susu kambing patut diperhatikan karena dapat membahayakan konsumen. Hal tersebut disebabkan $S$. aureus mampu menghasilkan toksin yang banyak menyebabkan foodborne atau milkborne diseases (Wang et al., 2012). Berdasarkan Standar Nasional Indonesia (SNI) No 01-6366-2000 tentang persyaratan susu segar, maka jumlah $S$. aureus yang diperbolehkan maksimal $1 \times 10^{2} \mathrm{CFU} / \mathrm{mL}$ (BSN, 2010). Saat ini jumlah $S$. aureus dalam susu kambing mengacu SNI No 01-6366-2000 karena standar untuk susu kambing di Indonesia belum tersedia. Hal tersebut berbeda dengan negara lain yang sudah tersedia.

Rataan S. aureus pada susu kambing sebanyak $0,95 \times 10^{2} \mathrm{CFU} / \mathrm{mL}$ masih memenuhi SNI No 01 . $6366-2000$ sebanyak $86 \%$, sedangkan $13 \%$ sudah melebihi ketetapan SNI No 01-6366-2000 dan S. aureus yang berhasil diisolasi sebanyak $66 \%$ (Tabel 1). Hasil tersebut masih lebih kecil jika dibandingkan dengan penelitian Suwito et al. (2014a) bahwa susu kambing dari Kabupaten Sleman memiliki rataan $S$. aureus $5,75 \times 10^{3} \mathrm{CFU} / \mathrm{mL}$. Di Australia, susu kambing yang memenuhi standar dan layak dikonsumsi apabila rataan $S$. aureus $1,4 \times 10^{2} \mathrm{CFU} / \mathrm{mL}$ (Eglezoz et al., 2008). Sementara itu Taufik et al. (2011) menyatakan bahwa susu kambing dari Bogor masih memenuhi standar SNI No 01-6366-2000 dengan rataan $S$. aureus $0,7 \times 10^{2} \mathrm{CFU} / \mathrm{mL}$. Perbedaan hasil tersebut kemungkinan disebabkan oleh banyak faktor seperti pemerah mencuci tangan sebelum melakukan pemerahan, pencucian permukaan kulit ambing sebagai tempat produksi susu, kebersihan tempat penampung susu, dan tempat penyimpanan susu. Jumlah $S$. aureus yang melebihi standar dapat disebabkan karena pemerah tidak mencuci tangan dengan sabun atau desinfektan, tidak menggunakan masker, dan sarung tangan saat memerah sehingga dapat mencemari susu (Alexopoulos et al., 2011). Pemerah yang tidak mencuci tangan sebelum melakukan pemerahan dapat menyebabkan peningka$\tan$ jumlah $S$. aureus, karena tangan pemerah sebagai sumber $S$. aureus. Selain tangan pemerah, sumber $S$. aureus antara lain kulit di sekitar ambing, kain yang digunakan untuk mengeringkan ambing, mesin pemerah, dan lingkungan sekitar kandang (Silanikove et al., 2014).

Tabel 1. Isolasi dan jumlah S.aureus pada susu kambing dan produk olahannya

\begin{tabular}{|c|c|c|c|}
\hline $\begin{array}{l}\text { Jenis } \\
\text { Sampel }\end{array}$ & Kode & $\begin{array}{l}\text { Konfirmasi } \\
\text { S. aureus }\end{array}$ & $\begin{array}{c}\text { Jumlah } \\
\text { S. aureus } \\
\text { (CFU/mL) }\end{array}$ \\
\hline \multirow{15}{*}{$\begin{array}{l}\text { Susu } \\
\text { Segar }\end{array}$} & S1 & + & $0,5 \times 10^{2}$ \\
\hline & s2 & - & - \\
\hline & S3 & + & $0.2 \times 10^{2}$ \\
\hline & S4 & + & $0,3 \times 10^{<}$ \\
\hline & S5 & + & $0,1 \times 10^{2}$ \\
\hline & S6 & + & $0,2 \times 10^{5}$ \\
\hline & S7 & - & - \\
\hline & S8 & - & - \\
\hline & s9 & + & $0,4 \times 10^{2}$ \\
\hline & S10 & + & $0,7 \times 10^{2}$ \\
\hline & S11 & - & - \\
\hline & S12 & - & - \\
\hline & $\mathrm{S} 13$ & + & $0,5 \times 10^{<}$ \\
\hline & S14 & + & $0,8 \times 10^{<}$ \\
\hline & S15 & + & $0,4 \times 10^{5 *}$ \\
\hline $\begin{array}{l}\text { Susu } \\
\text { Bubuk }\end{array}$ & B1 - B10 & - & $0,+$ \\
\hline Es kream & $\mathrm{E} 1-\mathrm{E} 6$ & - & - \\
\hline Yoghurt & $Y 1-Y 4$ & - & - \\
\hline Permen & $P 1-P 3$ & - & - \\
\hline Krupuk & $\mathrm{K} 1-\mathrm{K} 3$ & - & - \\
\hline Rataan & & 66 & $\begin{array}{c}0,95 \times 10^{2} \pm 1,19 \\
\times 10^{2}\end{array}$ \\
\hline $\begin{array}{l}\text { Prosen- } \\
\text { tase (\%) }\end{array}$ & & & $\begin{array}{c}\text { < SNI 01-6366- } \\
2000: 86 \\
>\text { SNI 01-6366- } \\
2000: 13\end{array}$ \\
\hline
\end{tabular}

Produk olahan berbasis susu kambing seperti susu bubuk, permen, krupuk, yoghurt, dan es krim tidak ditemukan $S$. aureus (Tabel 1). Penelitian tersebut menunjukkan bahwa prevalensi $S$. aureus dalam produk olahan yang berbasis susu kambing $0 \%$. Sementara itu Xing et al. (2016) melaporkan bahwa prevalensi $S$. aureus pada susu kambing bubuk di propinsi Shaanxi Cina sebanyak 10,4\%. Tidak ditemukannya $S$. aureus dalam produk olahan tersebut kemungkinan saat pengolahan maupun penyimpanan tidak terjadi kontaminasi. Kontaminasi $S$. aureus dalam produk susu kambing berasal dari penanganan yang tidak benar seperti tidak menggunakan masker atau sarung tangan saat pengolahan (Jamali et al., 2015). 
Faktor virulensi hemolisin $S$. aureus dari susu kambing disajikan dalam (Tabel 2). Hemolisin tipe $Y$ atau tidak hemolitik paling banyak ditemukan yaitu $80 \%$, tipe $\beta 20 \%$, sedangkan tipe $\alpha$ tidak ditemukan. Sementara itu penelitian Suwito et al. (2014b) menunjukkan dari 7 isolat Staphylococcus spp., penyebab mastitis subklinis pada kambing peranakan Ettawa (PE) terdapat 5 isolat hemolitik $\beta$ dan tidak hemolitik 2 isolat. Hemolisin tipe $B$ paling banyak dijumpai pada Staphylococcus spp (Tong et al., 2015).

Tabel 2. Karakterisasi S.aureus dari susu kambing

\begin{tabular}{lccccc}
\hline \multirow{2}{*}{$\begin{array}{c}\text { Kode } \\
\text { Isolat }\end{array}$} & \multicolumn{3}{c}{$\begin{array}{c}\text { Heduksi } \\
\text { Hemolisin }\end{array}$} & $\begin{array}{c}\text { Klumping } \\
\text { Faktor }\end{array}$ & $\begin{array}{c}\text { Koa- } \\
\text { gulase }\end{array}$ \\
\cline { 2 - 4 } S1 & a & B & Y & & \\
S3 & - & + & - & + & + \\
S4 & - & - & + & - & - \\
S5 & - & - & + & - & - \\
S6 & - & - & + & - & - \\
S9 & - & - & + & - & - \\
S10 & - & - & + & - & + \\
S13 & - & + & - & - & + \\
S14 & - & - & + & - & - \\
S15 & - & - & + & + & + \\
\hline Prosentase & - & - & + & - & - \\
(\%) & 0 & 20 & 80 & 20 & 40 \\
\hline
\end{tabular}

Hemolisin berperan dalam menghemolisis sel darah merah. Infeksi $S$. aureus dengan hemolisin tipe $\alpha$ atau $\beta$ menyebabkan sel darah merah mengalami lisis. Staphylococcus aureus tidak hemolitik dapat menyebabkan penyakit dengan faktor virulensi yang lain seperti enterotoksin, leukosidin, enzim degradasi, dan tipe antigen permukaan (Schelin et al., 2011). Klumping faktor dan koagulase merupakan faktor virulensi $S$. aureus dari susu kambing disajikan dalam (Tabel 2). Staphylococcus aureus dengan klumping faktor positif sebanyak $20 \%$, sedangkan koagulase positif $40 \%$. Penelitian Suwito et al. (2014b) menunjukkan dari 7 isolat Staphylo- coccus spp., penyebab mastitis subklinis pada kambing PE dengan koagulase dan klumping faktor positif hanya $28 \%$. Sementara itu $S$. aureus koagulase positif dari susu kambing memiliki gen coa atau penyandi koagulase positif sebanyak 97,39\% (Linage et al., 2012). Klumping faktor dan koagulase memiliki kesamaan mekanisme kerja, tetapi berbeda patogenesisnya (Schelin et al., 2011).

Sensitifitas $S$. aureus dari susu kambing terhadap beberapa antibiotik disajikan dalam (Tabel 3). Staphylococcus aureus resisten terhadap ampisilin dan penisilin $30 \%$, sedangkan resisten terhadap eritromisin, neomisin, sulfonamide, dan tetrasiklin masing-masing 10\%. Sebagian besar $S$. aureus dari hasil penelitian tersebut masih sensitif terhadap beberapa antibiotik, sehingga antibiotik tersebut masih layak apabila digunakan untuk mengatasi infeksi $S$. aureus yang berasal dari susu kambing. Selain itu, kemungkinan susu kambing tersebut berasal dari peternakan yang penggunaannya antibiotik masih sedikit atau jarang menggunakan. $S$. aureus yang resisten terhadap penisilin dapat disebabkan karena menghasilkan enzim $\beta$-laktamase yang merusak cincin $\beta$-laktam pada antibiotik golongan penisilin, akibatnya antibiotik tersebut tidak dapat bekerja dengan baik. Selain itu, $S$. aureus memiliki gen yang menyandi resistensi terhadap antibiotik. Di Cina $S$. aureus dari susu kambing bubuk resisten ampisilin $16,8 \%$, eritromisin $30,5 \%$, tetrasiklin $22,1 \%$, dan trimetoprim 89,5\% (Xing et al., 2016).

Hasil penelitian yang berbeda dilaporkan oleh Mehli et al. (2017) bahwa $S$. aureus dari keju semuanya sensitif terhadap eritromisin, tetrasiklin, neomisin, dan trimetoprim. Di negara Iran $S$. aureus dari susu kambing resisten penisilin, eritromisin, dan tetrasiklin masing-masing $51,2 \%, 4,7 \%, 58,1 \%$ dan resistensi tersebut disebabkan karena $S$. aureus memiliki gen blaZ 97,4\%, erm $A 42,3 \%$, tetM $20,2 \%$ (Jamali et al., 2015).

Tabel 3. Sensitifitas $S$.aureus dari susu kambing terhadap beberapa antibiotik

\begin{tabular}{|c|c|c|c|c|c|c|c|c|c|c|}
\hline Isolat & AMP & FOX & $E$ & $\mathrm{CN}$ & $\mathrm{N}$ & OX & OT & $\mathrm{P}$ & S3 & TE \\
\hline S1 & + & - & + & - & + & - & - & + & + & + \\
\hline S3 & - & - & - & - & - & - & - & - & - & - \\
\hline S4 & - & - & - & - & - & - & - & - & - & - \\
\hline S5 & - & - & - & - & - & - & - & + & - & - \\
\hline S6 & - & - & - & - & - & - & - & - & - & - \\
\hline S9 & - & - & - & - & - & - & - & + & - & - \\
\hline S10 & + & - & - & - & - & - & - & - & - & - \\
\hline S13 & - & - & - & - & - & - & - & - & - & - \\
\hline S14 & + & - & - & - & - & - & - & - & - & - \\
\hline S15 & - & - & - & - & - & - & - & - & - & - \\
\hline Prosentase (\%) & 30 & 0 & 10 & 0 & 10 & 0 & 0 & 30 & 10 & 10 \\
\hline
\end{tabular}

Keterangan: +: Resisten; - : Sensitif

AMP: ampisilin $10 \mu \mathrm{g}$, FOX: cefoksitin $30 \mu \mathrm{g}$, E: eritromisin $15 \mu \mathrm{g}$

$\mathrm{CN}$ : gentamisin $10 \mu \mathrm{g}, \mathrm{N}$ : neomisin $30 \mu \mathrm{g}$, OX: oksasilin $5 \mu \mathrm{g}$

OT: oksitetrasiklin $30 \mu \mathrm{g}, \mathrm{P}$ : penisilin G $10 \mathrm{IU}, \mathrm{S} 3$ : sulfonamide: $300 \mu \mathrm{g}$ TE: tetrasiklin $30 \mu \mathrm{g}$ 


\section{KESIMPULAN}

Staphylococcus aureus hanya ditemukan pada susu kambing yang masih mentah atau belum diolah, sedangkan pada produk olahan berbasis susu kambing tidak ditemukan. Sebagian besar $S$. aureus dari susu kambing tidak hemolitik $80 \%$, koagulase positif $40 \%$, klumping faktor positif $20 \%$, resisten terhadap antibiotik ampisilin dan penisilin $30 \%$, sedangkan resisten terhadap eritromisin, neomisin, sulfonamide, dan tetrasiklin masing-masing $10 \%$.

\section{UCAPAN TERIMAKASIH}

Ucapan terima kasih disampaikan kepada Badan Litbang Pertanian melalui KP3SL tahun 2015 yang telah memberikan dana penelitian sehingga penelitian ini dapat berlangsung.

\section{DAFTAR PUSTAKA}

Albenzio M, Santillo A. 2011. Biochemical characteristics of ewe and goat milk: Effect on the quality of dairy products. Small Ruminant Res 101: 33-40. DOI: 10.1016/j.smallrumres.2011. 09.023.

Alexopoulos A, Tzatzimakis G, Bezirtzoglou E, Plessas S, Stavropoulou E, Sinapis E, Abas Z. 2011. Microbiological quality and related factors of sheep milk produced in farms of NE Greece. Anaerobe 17: 276-279. DOI: 10.1016/j.ana erobe.2011.03.011.

[BAM] Bacterial Analytical Manual. 2011. Chapter 12 Staphylococcus aureus in foods. Food and Drug Administration. http://www.fda.gov. [10 Pebruari 2013].

[BSN] Badan Standarisasi Nasional. 2010. SNI $01-$ 6366-2000 tentang batas Maksimum Cemaran Mikroba dan Batas Maksimum Residu dalam Bahan Makanan Asal Hewan. 2-3. Jakarta: Badan Standarisasi Nasional

Ceballos LS, Morales ER, Adarve GDLT, Castro JD, Martinez LP, Sampelayo MRS. 2009. Composition of goat and cow milk produced under similar conditions and analyzed by identical methodology. J Food Compos Anal 22: 322-329. DOI: 10.1016/j.jfca.2008.10.020.

[CLSI] Clinical and Laboratory Standards Institute. 2012. Performance Standards for Antimicrobial Susceptibility Testing. Twenty-Second Informational Supplement. 32: 70-78. USA: Clinical and Laboratory Standards Institute.
Eglezoz S, Huang B, Gary A, Dykes N, Fegan, Bell K, Stuttard E. 2008. A survey of microbiological quality of frozen unpasteurised goats' milk in Queensland, Australia. Aust J Dairy Technol 63 79-81.

Ertas N, Gonulalan Z, Yildirim Y, Kum E. 2010. Detection of Staphylococcus aureus enterotoxins in sheep cheese and dairy desserts by multiplex PCR technique. Int J Food Microbiol 142: 74-77. DOI: 10.1016/j.ijfoodmicro.2010.06. 002.

Jamali H, Paydar M, Radmehr B, Ismail S, Dadrasnia A. 2015. Prevalence and antimicrobial resistance of Staphylococcus aureus isolated from raw milk and dairy products. Food Control 54: 383-388. DOI: 10.1016/j.foodcont. 2015.02.013.

Linage B, Calleja JMR, Otero A, Lopez LMG, Santos JA. 2012. Characterization of coagulasepositive staphylococci isolated from tank and silo ewe milk. J Dairy Sci 95: 1639-1644. DOI: 10.3168/jds.2011-4734.

Mehli L, Hoel S, Thomassen GMB, Jakobsen AN, Karlsen H. 2017. The prevalence, genetic diversity and antibiotic resistance of Staphylococcus aureus in milk, whey, and cheese from artisan farm dairies. Int Dairy J 65: 20-27. DOI: 10.1016/j.idairyj.2016.10.006.

Ribeiro AC. 2010. Speciality products made from goat milk. Small Ruminant Res 89: 225-223. DOI: 10.1016/j.smallrumres.2009.12.048.

Schelin J, Carlquist NW, Cohn MT, Lindqvist R, Barker GC. 2011. The formation of Staphylococcus aureus enterotoxin in food environments and advances in risk assessment. J Virulence 2: 580-592. DOI: 10.4161/viru.2.6.18122.

Silanikove N, Merin U, Leitner G. 2014. On effects of subclinical mastitis and stage of lactation on milk quality in goats. Small Ruminant Res 122: 76-82. DOI: 10.1016/j.smallrumres.2014.07.01 8.

[SIDa] Sistem Informasi Daerah. 2013. Sistem informasi daerah Kabupaten Sleman prioritaskan 4 komoditas unggulan. Badan Perencanaan Pembangunan Daerah Kabupaten Sleman. Sleman: Badan Perencanaan Pembangunan Daerah. http://www.bappeda.slemankab.go.id [20 November 2015].

Suwito W, Nugroho WS, Wahyuni AETH, Sumiarto B. 2014a. Analisis mikrobiologi susu kambing peranakan Ettawa (PE) dari kabupaten Sleman Yogyakarta. J Ked Hewan 8: 101-104. 
Suwito W, Nugroho WS, Wahyuni AETH, Sumiarto B. 2014b. Virulance factor of Staphylococcus spp., isolated from subclinical mastitis in Ettawa Grade goat' milk in Sleman regency-Yogyakarta. J Indonesian Trop Anim Agri 39: 52-57.

Taufik E, Hildebrandt G, Kleer JN, Wirjantoro TI, Kreausukon K, Zessin KH, Baumann MPO, Pasaribu FH. 2011. Microbiological quality of raw goat milk in Bogor Indonesia. Media Peternakan 34: 105-111.

Tong SYC, Davis JS, Eichenberger E, Holland TL, Fowler VG. 2015. Staphylococcus aureus infections, epidemiology, pathophysiology, clinical manifestations, and management. Clin Micro- biol Rev 28: 605-608. DOI: 10.1128/CMR. 00134-14.

Wang $X$, Meng J, Zhang J, Zhou T, Zhang Y, Yang $B, \quad X \quad M, X i a$ 2012. Characterization of Staphylococcus aureus isolated from powdered infant formula milk and infant rice cereal in China. Int J Food Microbiol 153: 142-147. DOI: 10.1016/j.ijfoodmicro.2011.10.030.

Xing $x$, Zhang $Y$, Wu Q, Wang X, Ge W, Wu C. 2016. Prevalence and characterization of Staphylococcus aureus isolated from goat milk powder processing plants. Food Control 59: 644-650. DOI: 10.1016/j.foodcont.2015.06.042. 